\title{
The status of limnophilic fish and the need for conservation in floodplains along the lower Rhine, a large regulated river
}

\author{
R. E. Grift ${ }^{1}$, A. D. Buijse ${ }^{2 \star}$ and G. J. van Geest ${ }^{3}$ \\ With 6 figures and 4 tables in the text
}

\begin{abstract}
Recovery of the fish community of the river Rhine focussed mainly on the return of migratory species, in particular the Atlantic Salmon, Salmo salar, and to a lesser extent on rheophilic fish species. Several limnophilic species that characterize remote parts of the floodplains are, however, also endangered.

The status of the fish communities in the floodplains is little known and has been neglected so far. To fill this gap, the present study investigated fish communities in floodplain lakes along the lower River Rhine. To assess how these lakes contribute to fish species richness in the river-floodplain system, the community structure is compared to that in the main channel and to connected backwaters, e.g. side channels, which had been investigated more intensively in recent years.

Floodplain lakes with abundant vegetation may have low fish species richness, but they are the only sites with suitable habitats for the reproduction of limnophilic species such as tench Tinca tinca, rudd Scardinius erythrophthalmus and crucian carp Carassius carassius. Limnophilic species in most of these lakes are, however, outnumbered by eurytopic species such as bream Abramis brama, which indicates that the original lateral gradient is truncated with an almost complete loss of 'black fish' habitats in the present active floodplains along the lower Rhine.

Floodplain lakes with abundant vegetation should be carefully preserved because they represent original aquatic components that have declined markedly, and they need decades to develop. Preservation of these lakes would enhance the conservation of characteristic limnophilic species. Retention areas outside the present active floodplain - retained as a component of flood risk management - may provide the opportunity to rehabilitate or
\end{abstract}

Authors' addresses: ${ }^{1}$ Wageningen Imares-Institute for Marine Resources and Ecosystem Studies, Wageningen University and Research Centre, P. O. Box 68, 1970 AB IJmuiden, The Netherlands. $-{ }^{2}$ Institute for Inland Water Management and Waste Water Treatment (Rijkswaterstaat-RIZA), P. O. Box 17, 8200 AA Lelystad, The Netherlands; E-Mail: a.d.Buijse@riza.rws.minvenw.nl. - ${ }^{3}$ Centre for Limnology (NIOO-KNAW), Rijksstraatweg 6, 3631 AC Nieuwersluis, The Netherlands.

* Corresponding author 
create floodplain lakes with the suitable spawning and nursery habitats for limnophilic fish. In this way, improved safety may be combined with rehabilitation of floodplain water bodies.

Key words: rheophilic, eurytopic, floodplain rehabilitation, connectivity, species richness.

\section{Introduction}

Many large rivers in the world are heavily modified by damming, regulation and water abstraction and their accompanying floodplains or riverine wetlands are reclaimed by embankments with a significant loss of ecosystem function and structure, green services and biodiversity (DyNesIUs \& NILSSON 1994; BRINSON \& Malvarez 2002; Tockner \& STANFORD 2002). The lower Rhine in the Netherlands lost significant parts of its natural floodplains as early as around 1450 when the embankments were completed to protect the populated hinterland against flooding. Before that time, the area inundated during floods must have been kilometres wide, bounded only by the ridges of hills formed in the ice age (VAN URK \& SMIT 1989). These major embankments confined the present active floodplain to a width between 930 and $1460 \mathrm{~m}$ (BuIJSE et al. 2002). The most remote parts of the

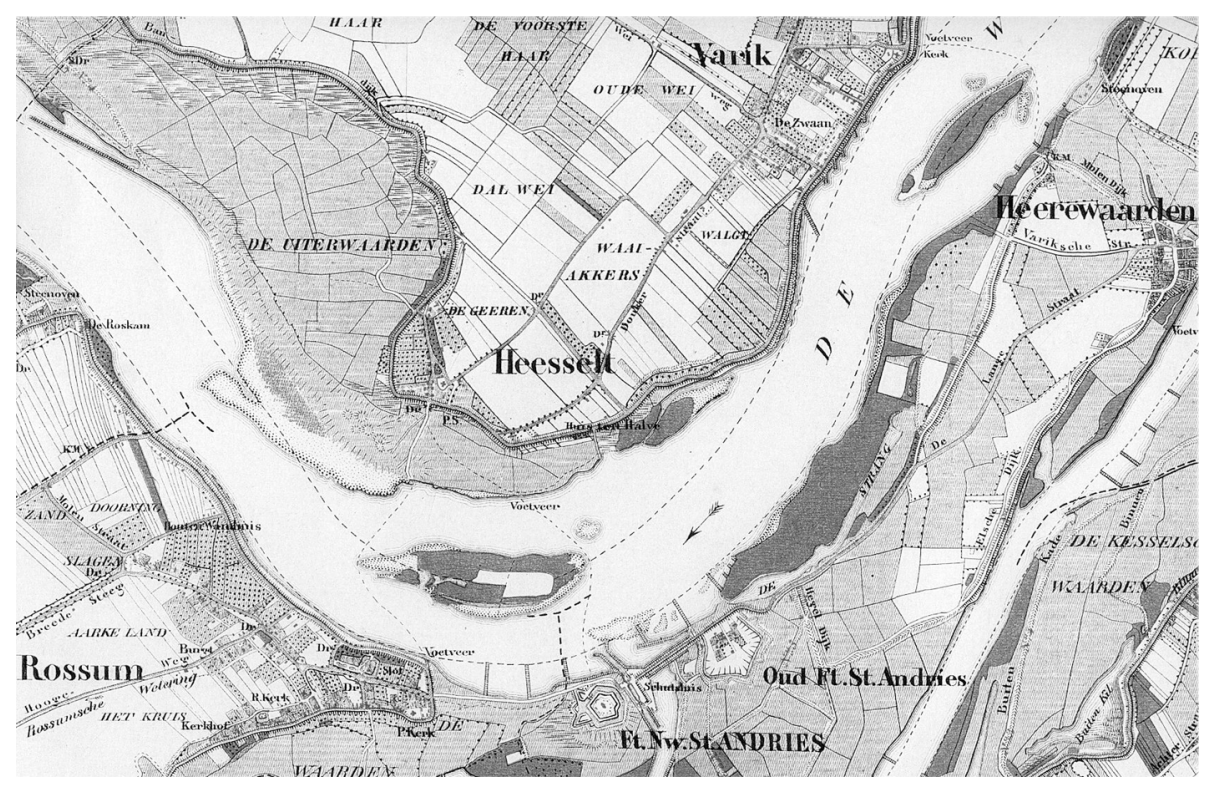

Fig. 1. A $5 \mathrm{~km}$ stretch (river-km 924-929) of the River Waal, the main and free-flowing branch of the River Rhine, prior to (A, above: 1872) and after the major normalizations (B, next page: 1912). The main channel is narrowed, islands have disappeared and the shoreline is fixed with groynes (source: Topografische Dienst). 
floodplains and characteristic 'black fish' habitats (sensu REGIER et al. 1989) that were previously seldom flooded have thus been completely disconnected from the river by major embankments for centuries.

To facilitate agriculture in the floodplains during the industrial revolution $\left(17^{\text {th }}\right.$ $18^{\text {th }}$ century), minor embankments were built between the remaining active floodplain and the main channel to prevent the cultivated areas from flooding in late spring and summer. This significantly decreased the frequency and duration of floodplain inundation. Due to the major embankments, in combination with two subsequent normalizations in the $19^{\text {th }}$ and $20^{\text {th }}$ century, the riverbed incised and the floodplains aggraded. These normalizations, which facilitated navigation and the discharge of water, sediments and ice, included cutting off some meanders, narrowing the riverbed and blocking lateral migration by fixing the shoreline with riprap and groynes (Fig. 1). The incised riverbed, formerly characterized by sand and gravel beds, nowadays has steep shorelines and low habitat variability (BUIJSE \& VRIESE 1996; MidDelKoOP 1997; Cals et al. 1998; SCHOOR et al. 1999; VAN DER Molen \& BuiJse 2005). This has resulted in the loss of the natural, gradual connection between the main channel and its floodplains. Furthermore, many natural water bodies with a permanent connection to the main channel were

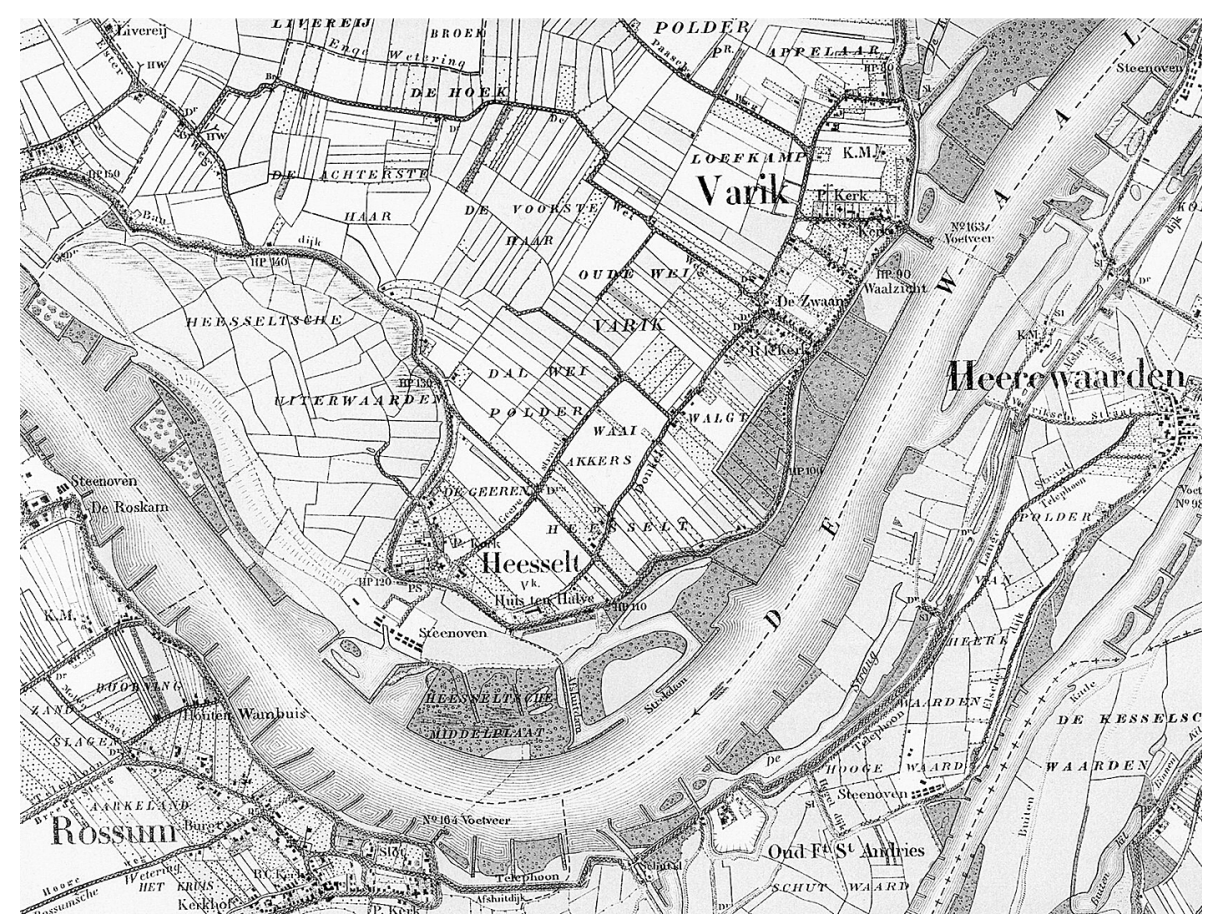

Fig. 1. B 
disconnected. The resulting regulated river landscape is a main channel with floodplains that presently inundate more rarely and abruptly and have little variation in frequency and duration of flooding (BUIJSE et al. 2002; VAN DER MOLEN \& BUIJSE 2005).

Variability of hydrological connectivity across a floodplain in a lateral direction supports high faunistic and floristic diversity (AMOROs \& Roux 1988; SCHIEMER et al. 1995; VAN DEN BRINK et al. 1996; SCHIEMER et al. 1999; TOCKNER et al. 1999; WARD et al. 1999; AMOROs \& BoRNETTE 2002). In natural floodplains, fish have adapted to the variability of connectivity and consequently there is a lateral gradient of fish reproduction in floodplain water bodies (COPP \& PEÑáz 1988; CopP 1989; Guti 1996; Leclerc \& Desgranges 2005). From the lotic main channel to lentic water bodies within the floodplains, fish community composition in more natural Central European lowland rivers shifts from rheophilic species (e.g. barbel Barbus barbus, ide Leuciscus idus) through eurytopic species (e.g. roach Rutilus rutilus, bream Abramis brama) to limnophilic species (e.g. tench Tinca tinca, weatherfish Misgurnus fossilis) (RegIER et al. 1989; SCHIEMER \& WAIDBACHER 1992; SCHIEMER et al. 1995; NAVODARU et al. 2002). The presence/absence of guilds can thus be used to assess the ecological integrity of rivers for fish (JUNGWIRTH et al. 2000; Schiemer 2000; AARTs \& Nienhuis 2003).

During the $20^{\text {th }}$ century, the total number of fish species in the lower Rhine has decreased due to the deterioration in physical habitat, combined with decreased water quality and overexploitation of commercially valuable migratory species. This has resulted in the decline of anadromous, rheophilic and limnophilic species (LeleK 1989; VAN DEN BRINK et al. 1990; RaAt 2001). The fish community has recovered substantially since its all-time low in the 1960s and 1970s (BRENNER et al. 2004; De LeEuw et al. 2005), but is, in the lower parts of the river, currently still strongly dominated by a few eurytopic species: pikeperch Sander lucioperca, bream, white bream Blicca bjoerkna and roach (BUIJSE \& CAZEMIER 1998; RAAT 2001). The first attention paid to the recovery of the fish community in the River Rhine focussed on the return of migratory species, in particular the Atlantic Salmon (Salmo salar) (BRENNER et al. 2004). In addition, rheophilic species occur in low numbers and most of them are listed on the Netherlands red list of endangered species because water quality deteriorated and suitable spawning and nursery areas are rare, have completely disappeared or are unreachable due to migration barriers (RAat 2001; Aarts et al. 2004; De Leeuw et al. 2005). Therefore, the spawning and nursery habitats of rheophilic fish species have been the focus of intensive studies in the Rhine in the Netherlands (BUIJSE \& VRIESE 1996; Grift et al. 2001b, 2003). These studies show that rheophilic fish are more common in permanently flowing side channels but also in backwaters that are only connected to the main channel at the downstream end. These connected backwaters were newly created to rehabilitate riparian habitats along the Rhine. As such they fulfil an important role in the recovery of the rheophilic guild, but currently there are only a few of these water bodies. The contribution of rheophilic species to the total fish community is 
Table 1. Characteristics of the floodplain water bodies sampled. Map numbers refer to Fig. 2; connectivity is the long term (1900-1995) average number of days per year during which the water body has been connected with the main channel. Locations: MC: main channel; GF: groyne fields; SC: side channel; COL: connected oxbow lake; SP: sand-pit; CP: clay-pit; OX: oxbow lake. Gears used: F: fyke nets; T: trawl; S: seine net; E: electro-fishing. The lower rows present the average values of the lakes studied and average values of all lakes present along the Waal.

\begin{tabular}{|c|c|c|c|c|c|c|c|c|c|}
\hline $\begin{array}{l}\text { Map } \\
\text { (No.) }\end{array}$ & $\begin{array}{l}\text { Latitude } \\
\text { (degrees, } \\
\text { North) }\end{array}$ & $\begin{array}{l}\text { Longitude } \\
\text { (degrees, } \\
\text { East) }\end{array}$ & $\begin{array}{l}\text { Surface } \\
\left(10^{4} \mathrm{~m}^{2}\right)\end{array}$ & $\begin{array}{l}\text { Depth } \\
\text { (Nov/ } \\
\text { Dec) } \\
(\mathrm{m})\end{array}$ & $\begin{array}{l}\text { Connect- } \\
\text { ivity } \\
\text { (days/year) }\end{array}$ & $\begin{array}{l}\text { Submerse } \\
\text { vegetation } \\
(\% \text { cover })\end{array}$ & $\begin{array}{c}\text { Floating } \\
\text { vegetation } \\
(\% \text { cover })\end{array}$ & $\begin{array}{l}\text { Helophytes } \\
\text { (\% cover) }\end{array}$ & $\begin{array}{c}\text { Gears } \\
\text { used }\end{array}$ \\
\hline$-\mathrm{MC}$ & & & 3900.0 & 4.0 & permanent & 0 & 0 & 0 & $\mathrm{~F}$ \\
\hline $\begin{array}{r}-\mathrm{MC} \\
(\mathrm{GF})\end{array}$ & & & 4.0 & 2.0 & permanent & 0 & 0 & 0 & $\mathrm{~S}, \mathrm{~T}$ \\
\hline $1 \mathrm{SC} 1$ & 51.827 & 5.313 & 13.6 & 1.5 & permanent & $0^{*}$ & 0 & 0 & $\mathrm{~S}, \mathrm{~T}$ \\
\hline $2 \mathrm{SC} 2$ & 51.891 & 5.536 & 26.9 & 1.5 & permanent & $0^{*}$ & 0 & 0 & $\mathrm{~S}, \mathrm{~T}$ \\
\hline $3 \mathrm{SC} 3$ & 51.808 & 5.206 & 8.4 & 1.0 & permanent & $0^{*}$ & 0 & 0 & $\mathrm{~S}, \mathrm{~T}$ \\
\hline $4 \mathrm{COL}$ & 51.871 & 5.418 & 5.4 & 2.5 & permanent & $0^{*}$ & 0 & 0 & $\mathrm{~S}, \mathrm{~T}$ \\
\hline $5 \mathrm{SP} 1$ & 51.866 & 5.964 & 5.0 & 2.0 & $2-20$ & 0 & 0 & 0 & $\mathrm{~S}, \mathrm{~T}$ \\
\hline $6 \mathrm{CP} 1$ & 51.877 & 5.980 & 0.7 & 1.5 & $2-20$ & 11 & 5 & 2 & $\mathrm{~S}, \mathrm{E}$ \\
\hline $7 \mathrm{CP} 2$ & 51.877 & 5.976 & 0.6 & 1.5 & $2-20$ & 0 & 10 & 2 & $\mathrm{~S}, \mathrm{E}$ \\
\hline $8 \mathrm{CP} 3$ & 51.876 & 5.984 & 0.7 & 1.0 & $2-20$ & 28 & 9 & 4 & $\mathrm{~S}, \mathrm{E}$ \\
\hline $9 \mathrm{CP} 4$ & 51.864 & 5.961 & 2.0 & 0.8 & $2-20$ & 4 & 0 & 0 & S \\
\hline $10 \mathrm{CP} 5$ & 51.886 & 5.920 & 1.4 & 0.8 & $2-20$ & 42 & 34 & 12 & $\mathrm{~S}, \mathrm{E}$ \\
\hline $11 \mathrm{CP} 6$ & 51.886 & 5.917 & 0.9 & 0.5 & $2-20$ & 0 & 75 & 20 & $\mathrm{E}$ \\
\hline $12 \mathrm{CP} 7$ & 51.887 & 5.911 & 4.0 & 1.5 & $2-20$ & 0 & 2 & 1 & S \\
\hline 13 CP8 & 51.895 & 5.664 & 8.0 & 1.5 & $50-150$ & 0 & 0 & 0 & S \\
\hline 14 CP9 & 51.892 & 5.654 & 2.0 & 1.0 & $50-150$ & 2 & 14 & 0 & S \\
\hline 15 CP11 & 51.826 & 5.334 & 0.1 & 0.8 & $2-20$ & 60 & 50 & 6 & $\mathrm{~S}, \mathrm{E}$ \\
\hline $16 \mathrm{CP} 12$ & 51.826 & 5.339 & 0.9 & 0.8 & $2-20$ & 57 & 46 & 6 & $\mathrm{E}$ \\
\hline 17 CP13 & 51.825 & 5.343 & 0.3 & 0.4 & $2-20$ & 89 & 0 & 5 & $\mathrm{E}$ \\
\hline $18 \mathrm{CP} 14$ & 51.824 & 5.330 & 1.3 & 0.8 & $2-20$ & 0 & 0 & 0 & $\mathrm{~S}$ \\
\hline $19 \mathrm{CP} 15$ & 51.911 & 5.584 & 0.2 & 1.0 & $2-20$ & 81 & 4 & 4 & $\mathrm{~S}, \mathrm{E}$ \\
\hline 20 OX1 & 51.861 & 5.877 & 3.5 & 1.5 & $50-150$ & 3 & 0 & 0 & $\mathrm{~S}$ \\
\hline $21 \mathrm{OX} 2$ & 51.882 & 5.740 & 12.6 & 2.5 & $50-150$ & 2 & 0 & 0 & $\mathrm{~S}, \mathrm{~T}$ \\
\hline $22 \mathrm{OX} 4$ & 51.822 & 5.328 & 0.2 & 1.5 & $2-20$ & 0 & 0 & 0 & $\mathrm{~S}$ \\
\hline 23 OX5 & 51.829 & 5.315 & 1.8 & 0.8 & $2-20$ & 32 & 34 & 3 & $\mathrm{~S}, \mathrm{E}$ \\
\hline $24 \mathrm{OX} 7$ & 51.831 & 5.274 & 4.3 & 1.0 & $2-20$ & 5 & 50 & 3 & $\mathrm{~S}, \mathrm{E}$ \\
\hline \multicolumn{3}{|c|}{ Average of subset } & 1.2 & 3 & & 20 & 17 & 4 & \\
\hline \multicolumn{3}{|c|}{ Minimum present along Waal branch } & 0.2 & 0.04 & & 0 & 0 & 0 & \\
\hline \multicolumn{3}{|c|}{ Average present along Waal branch } & 1.4 & 3.4 & & 34 & 15 & 3 & \\
\hline \multicolumn{3}{|c|}{ Maximum present along Waal branch } & 5.4 & 19.8 & & 100 & 70 & 30 & \\
\hline
\end{tabular}

* Vegetation is present at higher water levels when terrestrial vegetation is inundated. This occurred in April/May, September, November and December 1998 and from January to July 1999 continuously. 
consequently rather small (SimONS et al. 2001; Buisse et al. 2002; VAN DER MOLEN $\&$ BUIJSE 2005).

The role of floodplains and the riparian land-water ecotone is often neglected (Schiemer et al. 1995; Halls \& Welcomme 2004), even though their role in fish recruitment has been identified since for a long time (WELCOMME 1979; BAYLEY 1991; SCHLOSSER 1991). Recent studies in floodplains along large rivers are e.g. the Mississippi River (Miranda \& LuCas 2004), the Murray-Darling Basin (KING et al. 2003), the River Amazon (Petry et al. 2003), the St. Lawrence River (LeClerC \& Desgranges 2005) and the River Danube (Navodaru et al. 2002). Floodplain lakes along the rivers Meuse and Rhine in the Netherlands have been studied intensively (VAN DEN BRINK 1994), but fish were hardly addressed in that study. In general, little attention has so far been given to fish communities in the floodplains of the lower Rhine (BUiJse \& VRIESE 1996; Molls 1999; GRIFT et al. 2001a) and this limited knowledge constrains decision making on future floodplain management. We do not know which endangered limnophilic species are still present in the floodplain lakes along the lower Rhine or which factors determine their presence. National fish monitoring programmes are concentrated in the main channel and a few large and connected deep sand-pits and harbours (De LeEuw et al. 2005). Other than this monitoring, floodplain fish communities had only been investigated in water bodies that are permanently connected to the river (GRIFT et al. 2001b, 2003). Therefore the present study assessed fish species richness of 20 floodplain lakes along the lower River Rhine. These lakes are temporarily connected to the main channel during lesser or greater flood events. The fish communities in these 20 lakes are compared with results from other studies in the main channel and permanently connected floodplain water bodies (Table 1). Consequently, fish community structure was assessed along a gradient of connectivity with the main channel.

\section{Materials and methods}

\section{Study area}

The River Rhine, from its source in Switzerland to the outflow to the North Sea is now $1320 \mathrm{~km}$ long and has a catchment area of $185,000 \mathrm{~km}^{2}$ (LELEK 1989) of which the lower $25,000 \mathrm{~km}^{2}$ are situated in the Netherlands. Where the Rhine enters the Netherlands (at Lobith, Fig. 2), the average discharge is $2200 \mathrm{~m}^{3} \mathrm{~s}^{-1}$ (MidDELKoop \& VAN Haselen 1999). High precipitation and low evaporation in the catchment area cause a discharge peak in winter (Fig. 3). Just after crossing the border, the river splits into three branches of which the Waal branch transports $66 \%$ of the water and is free flowing. There are approximately 300 floodplain lakes along the Rhine branches in the Netherlands. During floods, these lakes become connected to the main stream and this mainly occurs in winter. 20 of these lakes along the Waal branch were sampled in the present study. Lakes were selected to represent variation in morphology (surface, depth, steepness of shores), hydrology (inundation fre- 


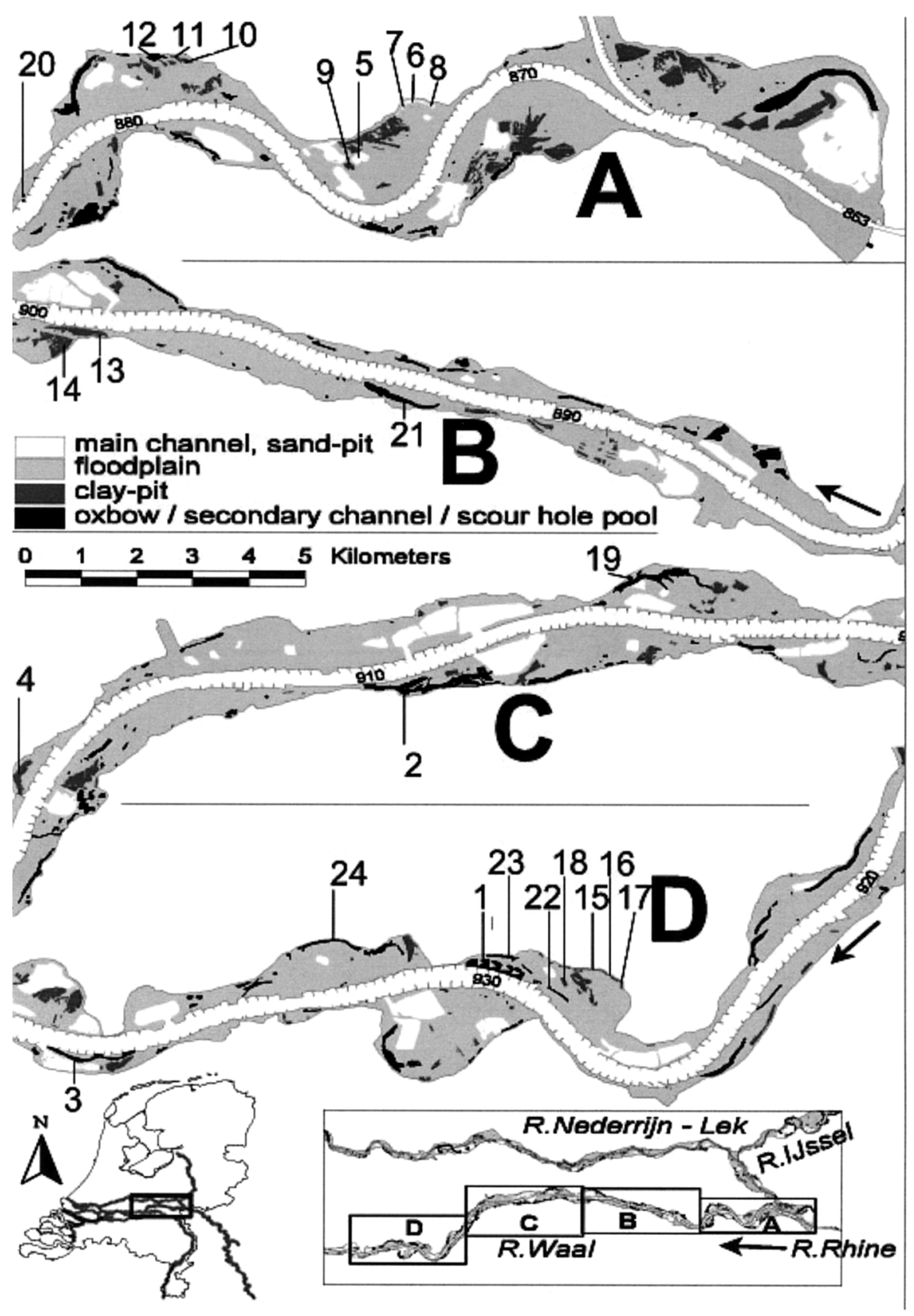

Fig. 2. The Waal branch of the River Rhine in the Netherlands with sampling locations. Numbers refer to the numbers in Table 1; arrows indicate direction of flow. 


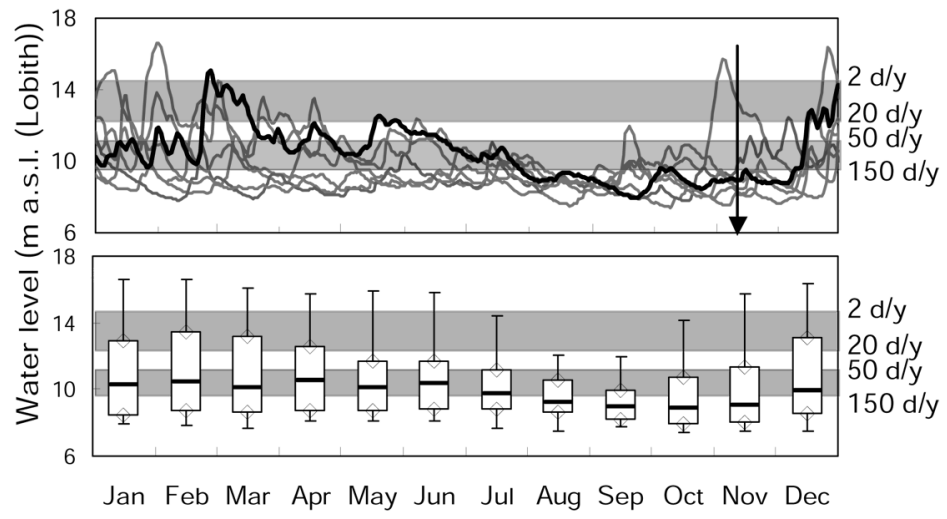

Fig. 3. Water levels of the River Rhine from 1993-1999 (upper panel) and from 19701999 (lower panel). Upper panel: Thick black line presents daily water levels in 1999; other lines, water levels in 1993-1998. Lower panel: Whisker and box plots present minimum and maximum water levels (whiskers) and the $0.10,0.50$ and 0.90 percentiles (boxes) per month (data from 1970-1999). In both panels grey bars present connection thresholds of lakes; lower grey bar: lakes connected $50-150 \mathrm{~d} \mathrm{yr}^{-1}(9.6-11.2 \mathrm{~m}$ a.s.1. at Lobith); upper grey bar: lakes connected 2-20 d yr ${ }^{-1}$ (12.4-14.7 m a.s.l. at Lobith); black arrow: 1999 sampling period.

quency) and the presence of aquatic vegetation. The distance between the most upstream and most downstream of these lakes is $61 \mathrm{~km}$ (Waal river-km 872-933). The average width of the floodplains in the study area is $550 \mathrm{~m}$. The lakes comprise man-made sand and clay-mining pits and natural oxbow lakes that have representative morphological and hydrological characteristics (Table 1).

From a hydrological perspective, the lakes are classified in two classes of inundation duration; lakes that lie between minor embankments and the main channel, are connected with the main channel for 50-150 days per year, lakes in between minor and major embankments are connected on average 2-20 days per year (Fig. 3). During the $20^{\text {th }}$ century (1900-1999), lakes from the first category were connected with the main channel at least once per year whereas, in the same period, lakes from the other category remained isolated in only nine years.

From a morphological point of view, all the lakes sampled are shallow $(=4 \mathrm{~m})$ but they vary in surface area ( 0.1 to $12.6 \mathrm{ha}$ ). Clay-pits (CP) are shallowest ( $<2 \mathrm{~m}$ deep) with steep $\left(>45^{\circ}\right)$ to nearly vertical banks and were excavated $40-120$ years ago. They are smaller than the oxbow lakes and vary in size from 0.1 to 8 ha. Their substrates consist of clay and sometimes silt. About half of the 14 clay-pits sampled lacked almost any aquatic vegetation while the vegetation in the other half was well developed and consisted of large stands of nymphaeids (Nuphar lutea and Nymphoides peltata), often accompanied by dense submerged vegetation consisting 
of Potamogeton pectinatus, P. trichoides or P. lucens. In some clay-pits, shore zones were covered with helophytes, mainly Sparganium erectum, Typha angustifolia or large Carex species.

Oxbow lakes (OX) are formed naturally and are the oldest floodplain lakes, aged 200 to 700 years. Due to net sedimentation in the floodplain, all lakes are subject to succession from open water to dry land. The age of these lakes influences the species composition of the vegetation; in older lakes water level fluctuations are reduced due to accumulation of clay and silt benefiting desiccation-sensitive species (VAN GEEsT et al. 2005). Their aquatic vegetation consists of nymphaeid species, but, in contrast to younger vegetated clay-pits, submerged vegetation is usually absent or scarce. Vegetation is absent from frequently inundated lakes (Table 1). Most oxbow lakes are shallow $(<1.5 \mathrm{~m})$, have gentle banks and sometimes, reed beds form extensive shallow ( $<0.5 \mathrm{~m}$ deep) areas. Their size varies from 0.2 to 12.6 ha and their substrates consist of silt and organic material.

The fish species composition of the floodplain lakes was compared with the species composition in the main channel and its groyne fields and in three permanently connected side channels and one oxbow lake connected at its downstream end (Table 1). The side channels (SC) and the connected oxbow lake (COL) were created for floodplain rehabilitation purposes in the 1990s. The main channel has low habitat variability, and sand, apart from the boulders covering the groynes, is the dominant substrate. The main channel has an average width of $380 \mathrm{~m}$. The permanently connected floodplain water bodies and groyne fields have comparable morphologies to the floodplain lakes; they had moderate depths $(<2.5 \mathrm{~m})$ and fine substrates (sand, clay or silt). The main channel, its groyne fields and side channels, however, differ strongly in their hydrological features from lakes. The main channel (MC) and its groyne fields (GF) are dynamic and rather inhospitable sites; there is a general high flow velocity (between 0.5 and $1.5 \mathrm{~m} \mathrm{~s}^{-1}$ ) and passing ships (on average every three minutes) cause strong eddies. In the side channels, moderately flowing water $\left(<0.3 \mathrm{~m} \mathrm{~s}^{-1}\right)$ is permanently present. Aquatic vegetation was scarce or absent in these habitats but for, on average, 120 days per year in spring and summer, terrestrial vegetation was inundated. A more detailed description of these locations is given in GRIFT et al. (2001b).

\section{Data collection}

The 20 floodplain lakes were sampled in November and December 1999. The large variation in habitats required the use of three different sampling techniques (Table 2). This period was chosen because it is well after the growing season and is therefore suited to assessment of both successful reproduction, using the presence of 0-group fish, as well as the survival of the enclosed fish community since the last connection to the main channel. The floodplain lakes were sampled with seine nets at sites without vegetation. Beds of aquatic vegetation and shore zones covered with helophytes were sampled by electric fishing. Deeper sites were 
Table 2. Characteristics of the sampling periods and gear types used.

\begin{tabular}{|c|c|c|c|c|}
\hline Water body & Date sampled & $\begin{array}{l}\text { Sampling } \\
\text { frequency }\end{array}$ & Gear used & $\begin{array}{l}\text { Gear size and } \\
\text { mesh size (\#) }\end{array}$ \\
\hline \multirow[t]{4}{*}{ Floodplain lakes } & Nov/Dec 1999 & Once & Seine & $100 \times 3 \mathrm{~m}(\# 14 \mathrm{~mm})$ \\
\hline & & & Seine & $200 \times 4 \mathrm{~m}(\# 14 \mathrm{~mm})$ \\
\hline & & & Electro fishing & $150 \mathrm{~V} / 5 \mathrm{~A}$ \\
\hline & & & Trawl & $7 \times 1 \mathrm{~m}(\# 17 \mathrm{~mm})$ \\
\hline \multirow[t]{2}{*}{ Main channel } & March 1999 & Once & Trawl $^{1}$ & $3 \times 0.5 \mathrm{~m}(\# 20 \mathrm{~mm})$ \\
\hline & April-October 1999 & Continuous & Fyke nets ${ }^{2}$ & $(\# 18-20 \mathrm{~mm})$ \\
\hline \multirow{4}{*}{$\begin{array}{l}\text { Side channels/ } \\
\text { Oxbow lake }\end{array}$} & March-December & 7 times & Seine & $100 \times 3 \mathrm{~m}(\# 14 \mathrm{~mm})$ \\
\hline & & & Electro fishing & $150 \mathrm{~V} / 5 \mathrm{~A}$ \\
\hline & 1999 (0-group fish) & 12 times & Seine & $16 \times 1 \mathrm{~m}(\# 7.5 \mathrm{~mm})$ \\
\hline & & & Trawl & $2 \times 0.5 \mathrm{~m}(\# 7.5 \mathrm{~mm})$ \\
\hline
\end{tabular}

${ }^{1}$ Data from STAm et al. (1999).

${ }^{2}$ From professional fishermen, data from WiNTER et al. (2000).

sampled with a bottom trawl that was towed behind two boats for 5 minutes. The seine nets and the trawl had comparable mesh sizes in the cod-end (17 and $20 \mathrm{~mm}$ ), so we assumed a comparable selectivity. The selectivity of the electric fishing is not well-known and cannot therefore be compared with the seine and trawl catches. In all lakes, however, electric fishing was executed in a standardized manner to minimize sampling differences among lakes. In each lake, the three types of habitat (shallow open water, shallow sites with vegetation, deep open water) were sampled representatively according to their proportion of the total surfac area. The fish caught were sedated in a chloride-butanol solution, species were identified and fork length measured to the nearest centimetre. All fish were kept in 'life nets' and set free at the end of each sampling day.

Data on fish communities in the main channel and floodplain water bodies with a permanent connection to the river were collected in other studies in 1998 and 1999 (Table 2). 0-group fish were sampled twelve times from April to September 1999 with fine meshed seine nets and trawls (sampling details in GRIFT et al. 2003). Several groyne fields were sampled along the main channel and we assumed that these data represent the 0-group fish assemblage in the main channel. 0-group fish were preserved in $4 \%$ formalin and identified in the laboratory (GRIFT et al. 2001b). Older fish were sampled in two side channels (SC1, SC2) and the reconnected oxbow lake seven times, evenly spread over the period March-December 1998.

In each lake, the percentage area covered by submerged, floating and emergent vegetation was estimated at 8-20 representative sites in July and August 1999 (VAN GEEST et al. 2005). The number of sites depended on lake size and the complexity of the vegetation structure. The surfaces of the lakes were calculated from a GIS database and depth was recorded with a portable echo sounder during the fish surveys. 


\section{Data analysis}

Fish species were classified into reproductive guilds according to SCHIEMER \& WAIDBACHER (1992). We grouped all fish that were born in the year of sampling as 0 -group and older fish as 1+. Age groups were distinguished by evaluating lengthfrequency distributions, which gave clear cut-off lengths for all species.

For comparison of biomasses among lakes, lengths were converted into weight using length-weight relationships retrieved from winter samplings in lacustrine systems in the Netherlands (unpubl. data).

Canonical correspondence analysis (Canoco software Version 4; TER BrAAK \& ŠMILAUER 1998) was selected to explore the relationship between species and lake characteristics (vegetation, depth, surface, inundation duration). Gear type used (seine, trawl, electro fishing) was included as an explanatory variable to distinguish possible effects of gear type from environmental effects. Therefore, the catch of one gear type in each lake was used as the sampling unit. Total numbers caught were square root transformed and the statistical significance of the effect of each environmental variable was tested using a Monte Carlo permutation test ( $\mathrm{p}<0.10 ; 1000$ random permutations).

\section{Results}

\section{Species richness}

The total number of species in individual floodplain lakes varied from 1-8 for 0group fish and from 2-13 for 1+ fish (Tables 3 and 4; Fig. 4). In contrast, in the main channel and the permanently connected water bodies the total number of species varied from 16-18 for 0-group fish and from 19-33 for the 1+ fish. This larger number of species was mainly due to the high number of rheophilic species such as barbel, nase Chondrostoma nasus and chub Leuciscus cephalus, that were absent from lakes which had become disconnected. Since most rheophilic and diadromous species are on the Netherlands red list of endangered species, this explains the higher number of red list species in the main channel and permanently connected water bodies (Fig. 4): a maximum of 7 red list species aged 1+ was observed in the main channel whereas a maximum of 2 was observed in the lakes. Some species occurred in the main channel which were not recorded at all in the other sites: limnophilic tenspined stickleback Pungitius pungitius, eurytopic wels Silurus glanis, diadromous sea trout Salmo trutta and sea lamprey Petromyzon marinus and the exotic grass carp Ctenopharyngodon idella and pumpkinseed Lepomis gibbosus.

The number of water bodies in which the individual fish species occurred, differed strongly among species. Within the limnophilic guild, sunbleak Leucaspius delineatus and rudd Scardinius erythrophthalmus were more widely distributed than crucian carp and tench. Within the eurytopic guild, bream and roach were the most widely distributed species occurring in 23 out of 25 water bodies. White bream, 


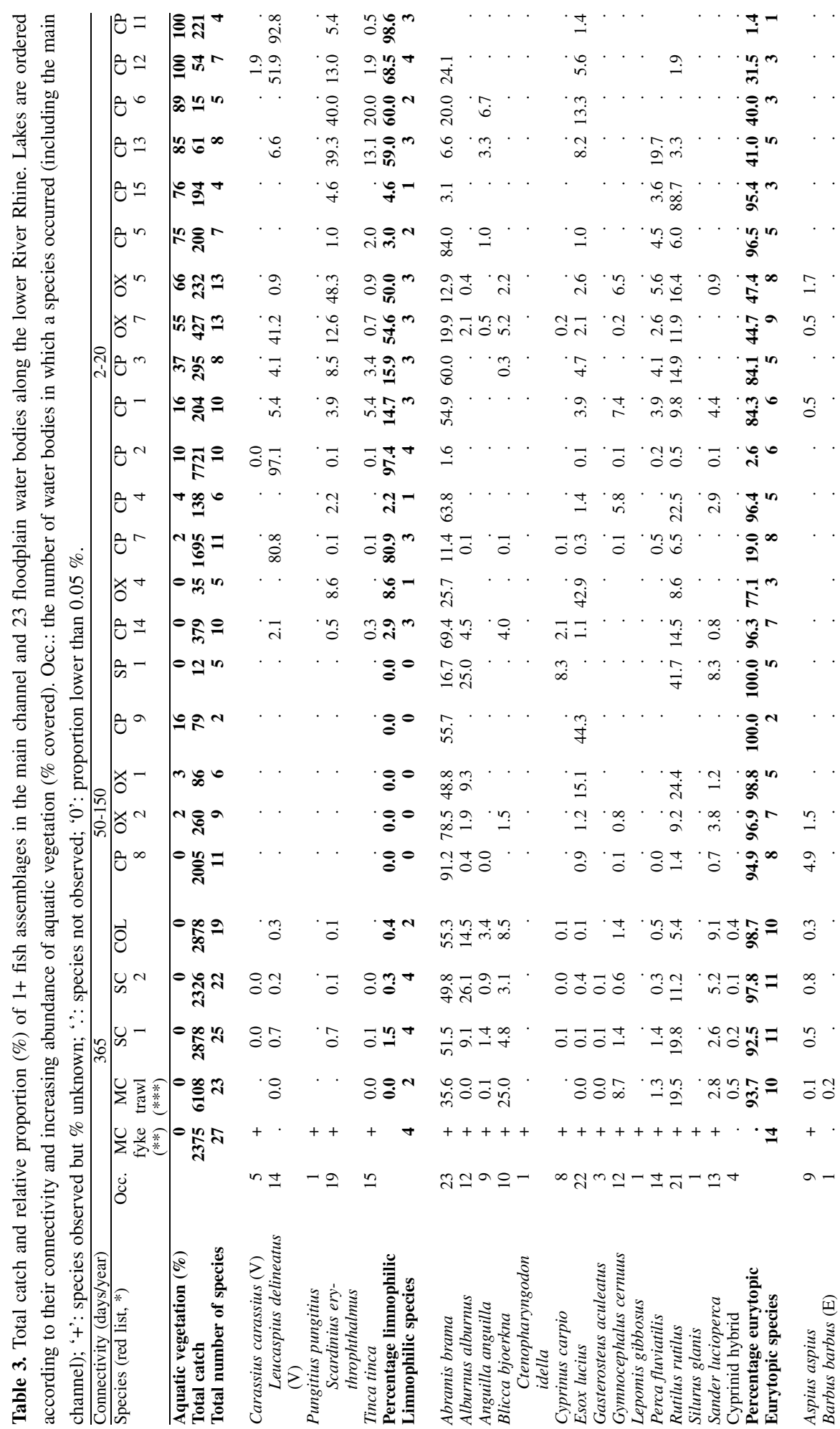




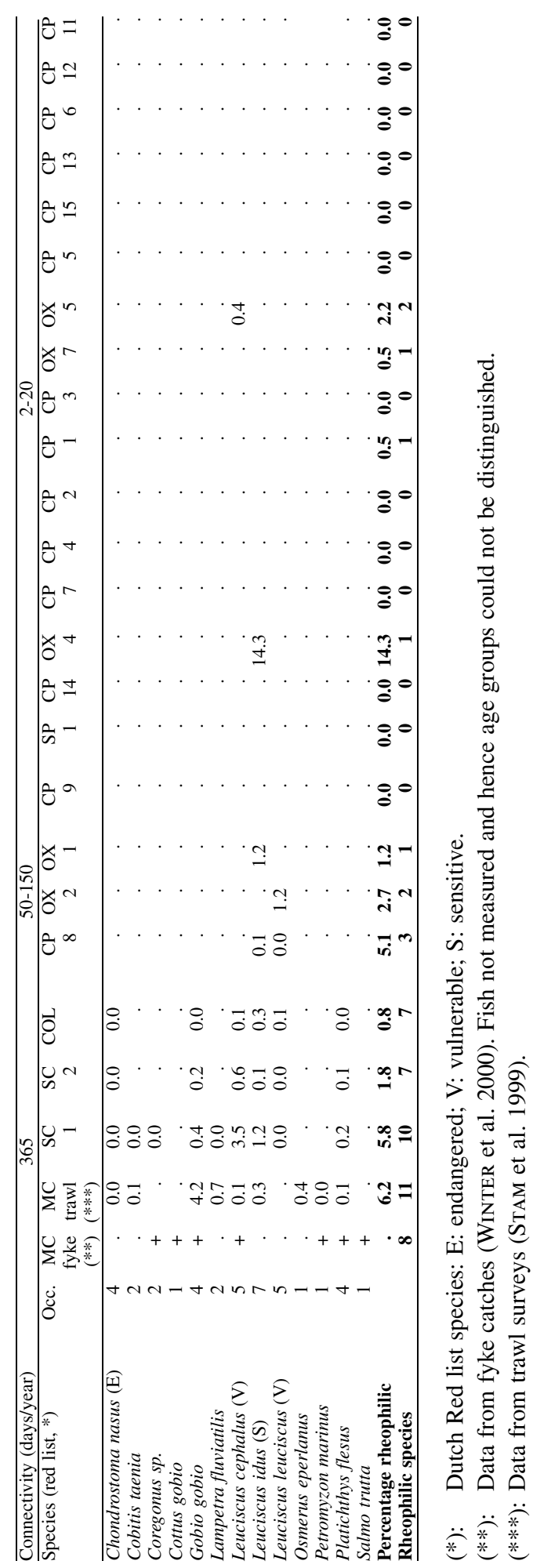




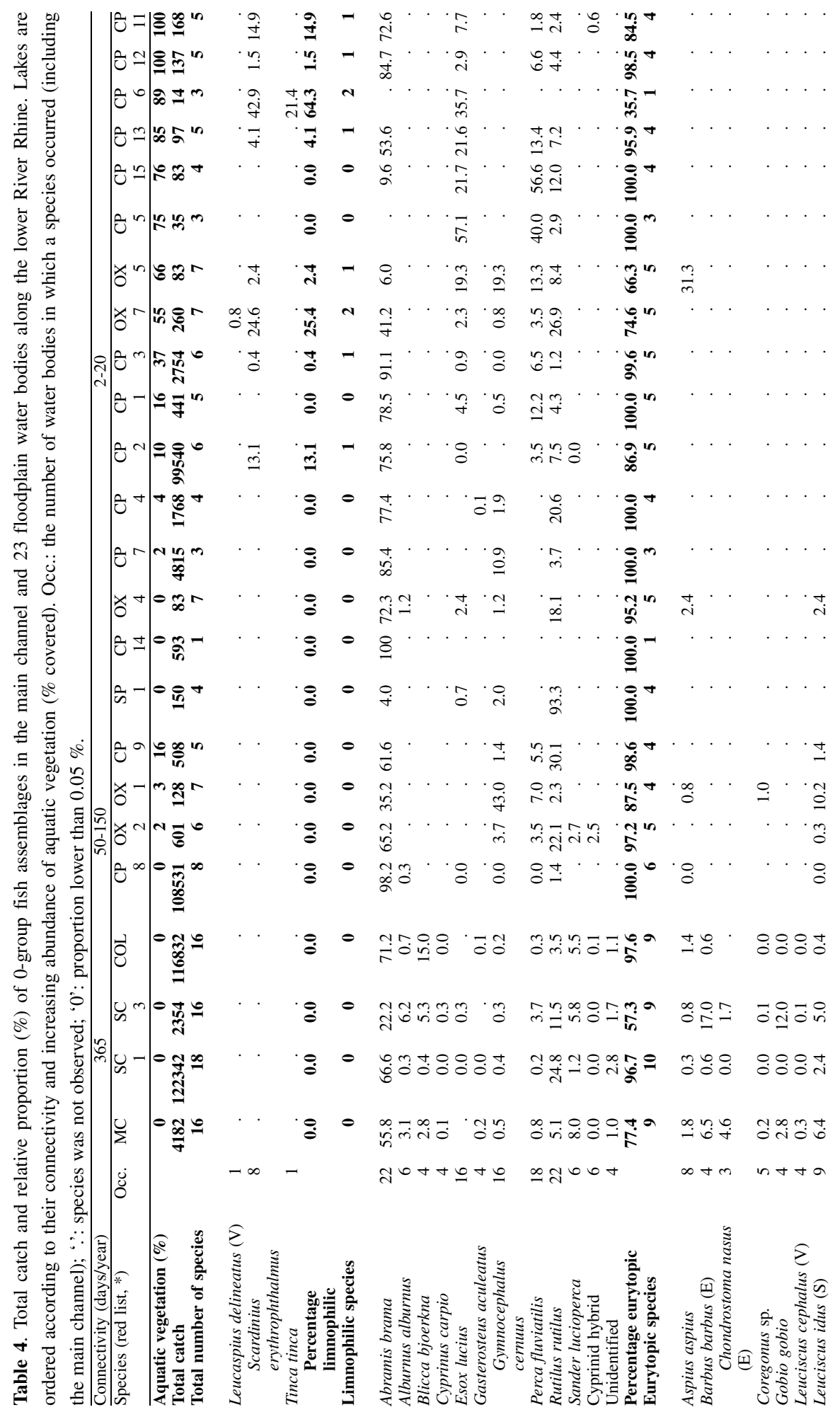




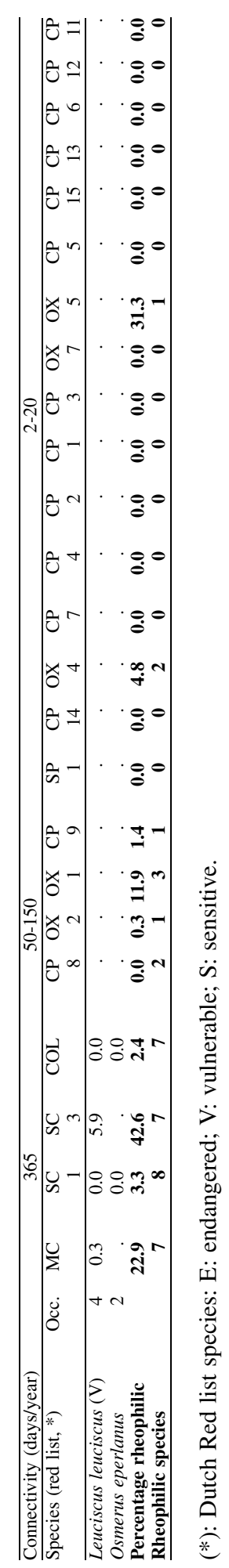




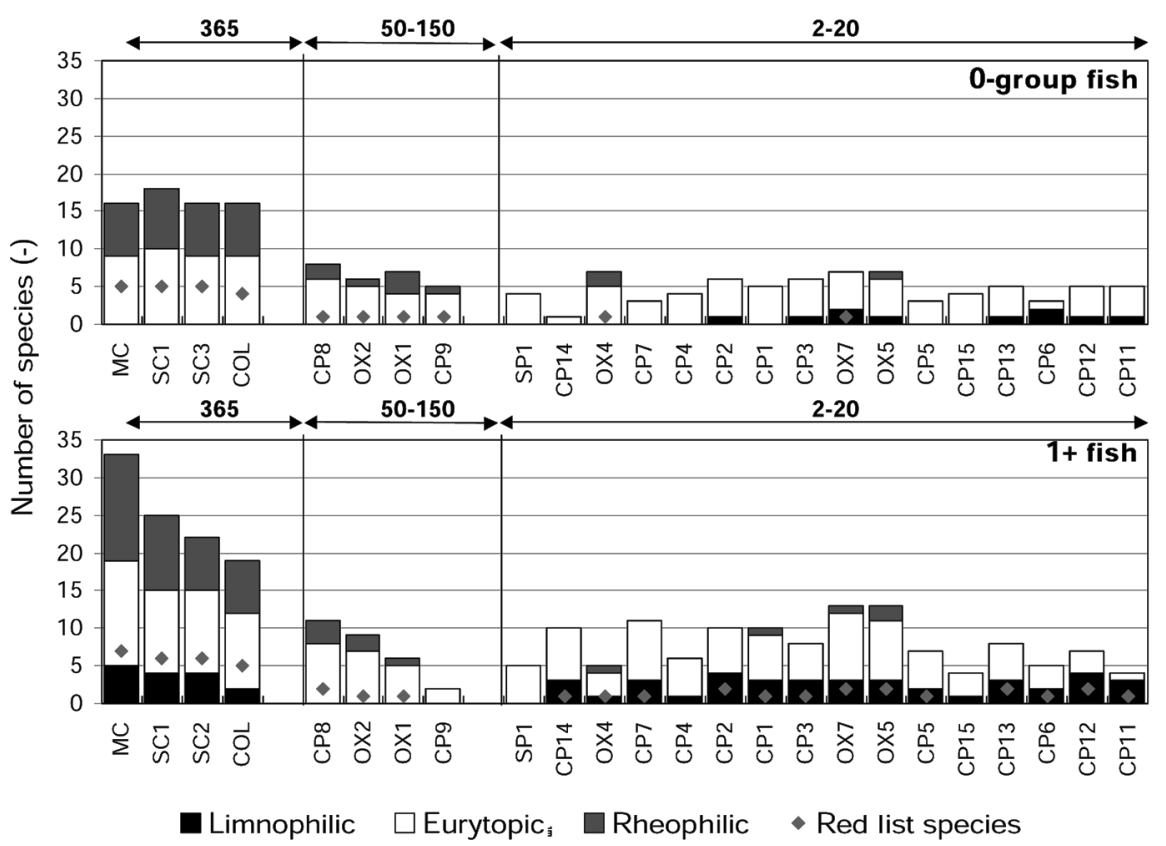

Fig. 4. Number of fish species per reproductive guild in the main channel and its groyne fields, side channels, connected oxbow lake and 20 floodplain lakes. Data for 1+ fish in the main channel are from fyke and trawl catches combined. Grey diamonds present number of species on the Dutch Red List.

Fig. 5. Distribution of fish in floodplain lakes along the River Rhine. Canonical correspondence analysis ordination diagram with fish species, floodplain lakes and environmental variables. Figures are the result of one analysis, but limnophilic and rheophilic species (panel a), eurytopic species (panel b) and lakes (panel c) are presented separately. The first and horizontal axis explains $16.7 \%$, the second axis $8.1 \%$ of the variation (model with only significant variables). Species are abbreviated with the first two letters of the genus and species name and their stage (0: 0-group fish; 1: 1+ fish). Black arrows indicate significant variables $(\mathrm{P}<0.10)$, grey arrows variables that were not significant; Inun: lake inundation frequency ; Surf: lake surface area; Depth: lake depth; Subm: percentage covered by submerse vegetation; Float: percentage covered by floating vegetation; TR: trawl used in sample; SE: seine used in sample; EL: electric fishing used. 


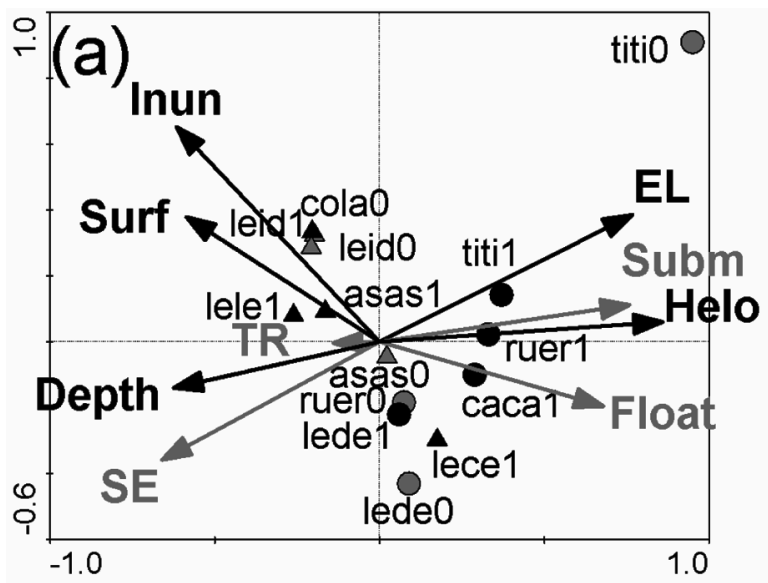

Limnophilic, 0-group

- Limnophilic, 1+

$\triangle$ Rheophilic, 0-group

A Rheophilic, 1+
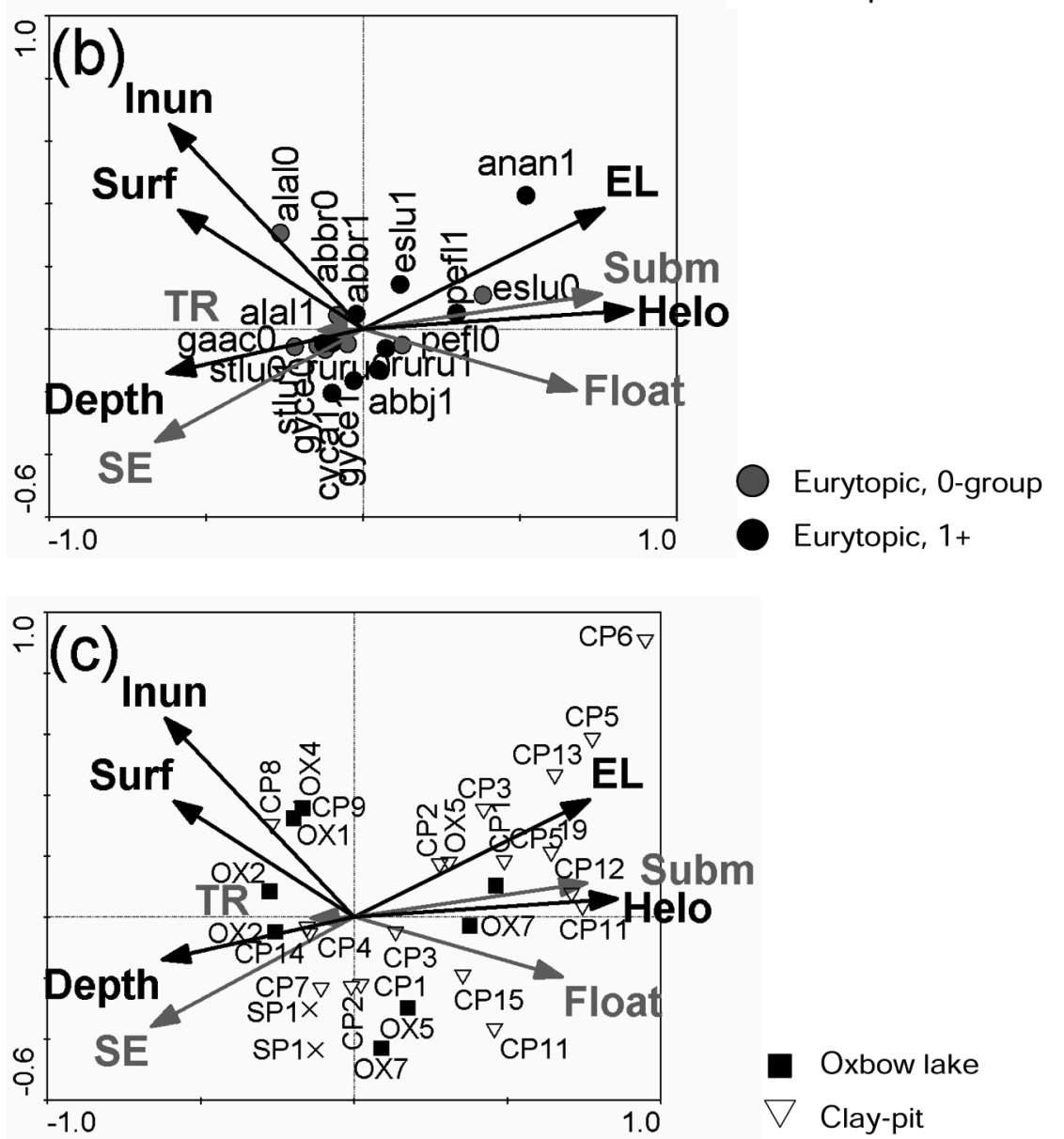
stickleback and common carp occurred in much fewer water bodies. Eurytopic and limnophilic $1+$ fish occurred both in water bodies that were permanently connected with the main channel and in the floodplain lakes that were inundated 2-20 days per year, whereas, $1+$ rheophilic fish were mainly limited to permanently connected floodplain water bodies. Remarkably, 1+ limnophilic fish were absent from all the frequently inundated lakes $\left(50-150 \mathrm{~d} \mathrm{yr}^{-1}\right)$.

Along a gradient of decreasing connectivity from the main channel the gradient in species occurrence was stronger for the 0-group than for 1+ fish (Tables 3, 4). In some lakes that are inundated 50-150 days per year, 0-group rheophilic asp Aspius aspius, ide and a coregonid species were present. Most probably these fish had migrated into these lakes in the preceding summer when the lakes became connected with the main channel (Fig. 3). Limnophilic 0-group fish were absent from these lakes, whereas they were present in lakes with low connectivity that were covered, at least to $10 \%$ with vegetation. In these vegetated lakes 0 -group rheophilic fish were not recorded. They were observed in all water bodies having a permanent connection to the main channel (Table 4). Eurytopic 0-group fish were present in almost every water body although 0-group bleak Alburnus alburnus, white bream, common carp Cyprinus carpio, stickleback Gasterosteus aculeatus and pikeperch were almost absent from the lakes.

\section{Fish species composition in floodplain lakes}

Abundance of helophytes, lake surface area, depth and the duration of connectivity had significant effects on the species composition in the floodplain lakes (Fig. 5). In addition, electric fishing contributed significantly to the species composition in the samples. Abundance of submerged and floating vegetation was not significant; they were strongly correlated with the abundance of helophytes. The use of the trawl and the seine was not significant as they correlated strongly with other factors (depth, electric fishing).

Limnophilic species were associated with shallow lakes with abundant vegetation (Fig. 5) where 0-group limnophilic fish contributed up to $64 \%$ of the total numbers of fish present (Tables 3,4). Limnophilic species such as rudd and sunbleak occurred frequently and made up large proportions of the fish community. Tench was observed in low numbers, but $1+$ tench were recorded in all lakes with abundant vegetation, except in CP15 (Table 3). Crucian carp were only observed in two small $(<1$ ha) vegetated lakes $(\mathrm{CP} 2, \mathrm{CP} 12)$. In lakes without vegetation, limnophilic species only contributed 0-3\% to the fish communities. Communities in these lakes were dominated by eurytopic bream, roach, perch Perca fluviatilis and, somewhat surprisingly, pike Esox lucius (Tables 3, 4). Within the eurytopic guild, perch and 0group pike occurred most frequently in lakes with abundant vegetation, whereas most other eurytopic species showed no clear preference (Fig. 4). Rheophilic species were associated with frequently inundated lakes without vegetation. 


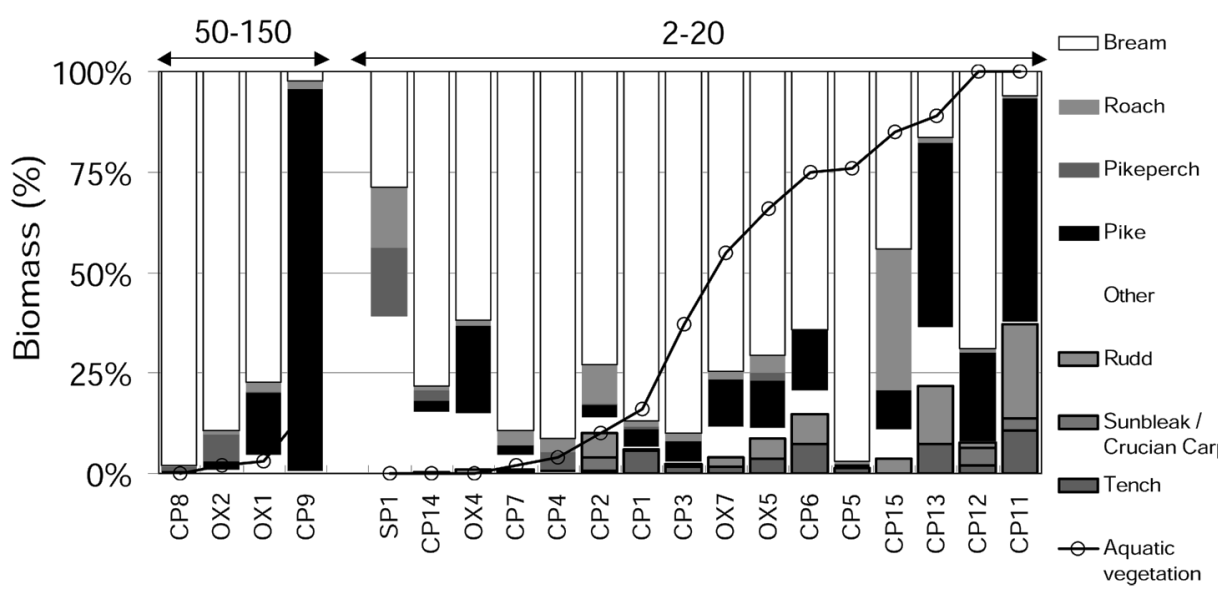

Fig. 6. Biomass composition of fish communities in 20 floodplain lakes. The lakes are ordered, first according their connectivity (arrows on top) and second according to increasing cover of aquatic vegetation (solid line; Table 1).

In terms of biomass, the fish communities in most (16) of the lakes were dominated (>50\%) by bream (Fig. 6). Limnophilic species were only important in some of the smaller clay-pits (CP11, CP13). The proportion of limnophilic species to the total fish biomass increased with increasing abundance of aquatic vegetation, but never exceeded $37 \%$. In lakes without vegetation, the proportion of limnophilic species to total biomass was always less than $1 \%$. Predatory pike contributed a large proportion $(>25 \%)$ of the total biomass in some of the smaller lakes with abundant vegetation (Fig. 6). In general, in smaller lakes with vegetation, pike was the most important predatory species, while in larger lakes without vegetation, pikeperch became more important (Fig. 6).

\section{Discussion}

Although we think that the fish communities were sampled representatively, conclusions cannot be drawn from data presented in this study without considering the sampling methodology. The variety of the environmental conditions in the water bodies sampled necessitated the use of different types of gear. The choice of gears was in line with the CEN prEN 14962 Water quality - Guidance on the scope and selection of fish sampling methods (CEN 2006). The sampling effort per water body was sufficiently high to ensure that the occurrence of species and species composition were sampled representatively in each of the water bodies. We do have, however, no further proof or statistical testing to support this assumption. The mesh sizes used in the lakes might have led to underestimation of 0-group fish of some 
species in the seine catches. The sampling regime encompassed a single survey of a large number (20) of water bodies so quantitative sampling methods were not feasible within the current project. Mark-recapture studies, which have been used in a complementary study in a single floodplain lake, are too labour-intensive for such a multi-lake survey and besides are only suitable for abundant species to achieve the required precision (GRIFT et al. 2001a). Multi-mesh gillnetting and poisoning of fish were impossible because permission was required from the organizations owning the fishing rights and such permission included keeping the fish alive, since all these floodplains are either situated in nature reserve areas or are important for recreational fisheries.

The lateral gradient of fish guilds from the main channel to the least connected floodplain lakes was in line with the classification of rheophilic, eurytopic and limnophilic species according to SCHIEMER \& WAIDBACHER (1992) and earlier work by others (e.g. Danube: GuTI 1996; Upper Rhône: Copp \& Peñáz 1988). From this point of view there is not much new in our study. The results, however, show that in the lower Rhine the gradient is no longer intact, but truncated at the landward side of the floodplains. We almost observed the complete range of fish species, but none of the floodplain lakes was dominated by limnophilic species, as is the case in more pristine rivers. Species characteristic of the most remote riverine wetlands, i.e. crucian carp and weatherfish, were observed respectively in very low numbers or not at all. BuiJse et al. (2002) compared the situation along the lower Rhine with those along the lower parts of the Danube. Both rivers have almost the same species diversity. In terms of biomass the Danube delta still has remote lakes dominated by limnophilic species (i.e. rudd or tench) and having substantial biomass of crucian carp (NAVODARU et al. 2002). Remote is here defined in terms of water travel time or water age, i.e. the time river water requires to reach the lake. Lakes along the Rhine may differ in connectivity, but water age in the narrow floodplains is very small, probably $<1 \mathrm{~d}$. So the embanked floodplains along the lower Rhine no longer cover the full array of habitats found in pristine systems. It is suspected that this situation has existed since the construction of the major embankments hundreds of years ago.

Vegetated floodplain lakes are the only suitable habitats where limnophilic species still reproduce successfully. They thus need to be identified and the most important ones may need conservation. Such lakes are relatively poor in fish species richness (5-8 species) compared to the main channel or connected backwaters (up to 28 species), but the species composition is sufficiently specific that they require special attention.

Frequent inundation of floodplain lakes with river water that has a small water age may prevent these lakes succeeding into a stage where they are dominated by limnophilic species. In natural lowland rivers, floodplain lakes undergo succession during which riparian plants colonise (AMOROs \& Roux 1988) and the various stages imply a succession of spawning opportunities for different fish species. In a final stage, when the former meander becomes heavily silted or choked with aquatic vegetation, fish reproduction is gradually reduced to exclusively limnophilic species 
(Copp et al. 1991), such as crucian carp and weatherfish, that are well adapted to withstand environmental conditions that may occur during drawdown or prolonged periods of isolation (Holopainen et al. 1997; Meyer \& Hinrichs 2000). Such conditions go beyond the tolerance limits of other species such as bream (BACKIEL \& ZAWISWA 1968) and roach. In natural floodplain lakes, differential mortality occurs of fish species with different life histories (Lowe-MCConNELl 1975; WeLCOMME 1979; MERron et al. 1993; WinEMILLER \& JEPSEN 1998; WinEMILLER et al. 2000), and may even determine species composition to a greater extent than immigration during connection (HALYK \& BALON 1983; TEJERINA-GARRo et al. 1998). Along the regulated and embanked lower Rhine almost all the floodplain lakes become connected to the main channel almost every year. The incoming river water, loaded with sediments, is expected to disturb or reset the succession process of these lakes (PetTs 1994; Heiler et al. 1995). Such flood disturbance may cause a decreasing species richness and abundance of aquatic macrophytes and helophytes (VAN DEN BRINK et al. 1991). Nowadays, remote lakes that were once seldom flooded and were in a final stage of succession, are situated in the hinterland outside the floodplain and have been disconnected from the river by major embankments for centuries. Consequently, floodplain lakes in which limnophilic species dominated have disappeared and new ones do not seem to have developed in the embanked floodplains.

At present, the national policy concerning major rivers in the Netherlands may provide the opportunity to improve the environmental conditions for both rheophilic and limnophilic fish species. The policy aims at sustainable flood risk management along the rivers that will be achieved through a combination of measures: i) strengthening the embankments, ii) giving the rivers more room, and iii) retaining water (Ministry of Transport, Public Works and Water Management 1998). The first measure has little ecological consequences for fish, but the latter two are complementary measures from which various fish species may selectively benefit. Rheophilic fish species certainly profit from recently created side channels and reconnected oxbow lakes (GRIFT et al. 2001b, 2003) and such connected channels enlarge the discharge capacity (BuIJse et al. 2002).

Retention areas outside the present active floodplains may provide opportunities to rehabilitate or create floodplain lakes that provide suitable habitats for limnophilic species. These retention areas will only become connected with the main channel during exceptional floods and consequently, they will seldom be connected and will remain isolated for long periods (Ministry of Transport, Public Works and Water Management 1998). If these retention areas are designed in such a way that aquatic vegetation can develop, they may compensate for the current scarcity of less dynamic floodplain lakes with abundant vegetation. In this way, reduced flood risk can be combined with rehabilitation of floodplain lakes.

Where it concerns conservation of present values, conditions in floodplain lakes may alter when connectivity is increased as a result of flood risk management in the present active floodplain. For floodplain lakes that are as yet without vegetation and 
have a rather 'uninteresting' eurytopic species composition this will likely improve substantially. This would allow rheophilic species to immigrate and emigrate at any time (GRIFT et al. 2001b, 2003; SimONs et al. 2001). With vegetated floodplain lakes more care is required, because they are the only source of habitat for the limnophilic fish guild along the River Rhine. This care is even more necessary when bitterling Rhodeus sericeus amarus or weatherfish are observed, both listed on Appendix II of the European Habitats Directive. Disruption of their habitats may be forbidden, especially since compensating their habitat loss with new ones is quite complicated, if not impossible, because their habitats need decades to develop naturally. This implies that vegetated floodplain lakes should first be assessed for their fish community structure before connectivity duration is modified by any management plan.

\section{Acknowledgements}

This project was financed by Rijkswaterstaat. We are grateful to Johan Merkx, Gerard De LaAK and Stephan Jansen for their assistance in the field, to Wouter Dubbeldam for creating the map with the sampling sites, to BrAm HuISMAN for critically reviewing earlier versions of the manuscript and to MARY MoRRIs for her valuable amendments of the English. We thank the three anonymous referees for their very constructive comments. Since this paper forms part of a special issue dedicated to the achievements of FrITZ SCHIEMER we would like to express our thanks for his achievements to rehabilitate rivers, for fish in particular. Within Europe he has given an enormous impetus to the use of fish, and especially the juveniles, as indicators for rivers. For the study on the River Rhine in particular his 1998 workshop in Vienna on 0+ fish was timely. Thereafter he participated in an invited workshop in the floodplain rehabilitation reserve 'Blauwe Kamer' and contributed significantly to the Ph.D. study of the first author and finally opposed during the defence of the Ph.D. thesis.

\section{References}

Aarts, B.G.W. \& Nienhuis, P.H. (2003): Fish zonations and guilds as the basis for assessment of ecological integrity of large rivers. - Hydrobiologia 500: 157-178.

Aarts, B.G.W., VAn DEN Brink, F.W.B. \& NiENhuis, P.H. (2004): Habitat loss as the main cause of the slow recovery of fish faunas of regulated large rivers in Europe: the transversal floodplain gradient. - River Res. Appl. 20: 3-23.

Amoros, C. \& BornetTe, G. (2002): Connectivity and biocomplexity in waterbodies of riverine floodplains. - Freshw. Biol. 47: 761-776.

Amoros, C. \& Roux, A.L. (1988): Interaction between water bodies within the floodplains of large rivers: function and development of connectivity. - In: SCHREIBER, K.-F. (ed.): Connectivity in landscape ecology. Münstersche Geograph. Arb. 29: 125-130.

BaCKIEL, T. \& ZaWIEWA, J. (1968): Synopsis on the biological data on the bream Abramis brama (Linnaeus, 1785). - FAO Fisheries synopsis 36: 110 pp; Rome.

BAYLEY, P.B. (1991): The flood pulse advantage and the restoration of river-floodplain systems. - Regul. Riv. Res. Managem. 6: 75-86. 
Brenner, T., Buijse, A.D., Lauff, M., Luquet, J.F. \& Staub, E. (2004): The present status of the River Rhine with special emphasis on fisheries development. - In: Welcomme, R. \& Petr, T. (eds.): Proceedings of the Second International Symposium on the Management of Large Rivers for Fisheries 1: 121-147. FAO Regional Office for Asia and the Pacific, Bangkok, Thailand. RAP Publ. 2004/16.

Brinson, M.M. \& MALVAREZ, A.I. (2002): Temperate freshwater wetlands: types, status and threats. - Environm. Conserv. 29: 115-133.

Buijse, A.D., Coops, H., Staras, M., Jans, L.H., Van Geest, G.J., Grift, R.E., Ibelings, B.W., OosterberG, W. \& Roozen, F.C.J.M. (2002): Restoration strategies for river floodplains along large lowland rivers in Europe. - Freshw. Biol. 47: 889-907.

Buisse, A.D. \& VRIESE, F.T. (1996): Assessing potential fish stocks in new nature developments in floodplains of large rivers in the Netherlands. - Arch. Hydrobiol. Suppl. 113 (Large Rivers 10): 339-343.

Buisse, T. \& Cazemier, W. (1998): Fischbestandserhebung im Rhein im Rahmen des landesweiten Ökosystem-Monitoringprogramms. - LÖBF-Mitt. 23: 47-56.

Cals, M.J.R., Postma, R., Buisse, A.D. \& Marteinn, E.C.L. (1998): Habitat restoration along the River Rhine in the Netherlands; putting ideas into practice. - Aquat. Conserv. Mar. Freshw. Ecosyst. 8: 61-70.

CEN (2006): prEN 14962 Water quality - Guidance on the scope and selection of fish sampling methods. -25 pp., Europ. Committee for Standardization, Brussels. (in prep.)

Copp, G.H. (1989): The habitat diversity and fish reproductive function of floodplain ecosystems. - Environ. Biol. Fishes 26: 1-27.

Copp, G.H., Oliver, J.M., Peñáz, M. \& Roux, A.L. (1991): Juvenile fishes as functional describers of fluvial ecosystem dynamics: Applications on the river Rhone, France. Regul. Rivers: Res. Mgmt. 6: 135-145.

Copp, G.H. \& Peñáz, M. (1988): Ecology of fish spawning and nursery zones in the floodplain, using a new sampling approach. - Hydrobiologia 169: 209-224.

De Leeuw, J.J., Buisse, A.D., Grift, R.E. \& Winter, H.V. (2005): Management and monitoring of the return of riverine fish species in the Netherlands. - Arch. Hydrobiol. Suppl. 155 (Large Rivers 15): 391-411.

Dynesius, M. \& Nilsson, C. (1994): Fragmentation and flow regulation of river systems in the northern third of the world. - Science 266: 753-762.

Grift, R.E., Buisse, A.D., Klein Breteler, J.G.P., Van Densen, W.L.T., Machiels, M.A.M. \& BACKx, J.J.G.M. (2001a): Migration of bream between the main channel and floodplain lakes along the lower River Rhine during the connection phase. - J. Fish Biol. 59: 1033-1055.

Grift, R.E., Buisse, A.D., Van Densen, W.L.T. \& Klein Breteler, J.G.P. (2001b): Restoration of the river-floodplain interaction: benefits for the fish community in the River Rhine. - Arch. Hydrobiol. Suppl. 135 (Large Rivers 12): 173-185.

Grift, R.E., Buijse, A.D., Van Densen, W.L.T., Machiels, M.A.M., Kranenbarg, J., Klein Breteler, J.G.P. \& BACKX, J.J.G.M. (2003): Suitable habitats for 0-group fish in rehabilitated floodplains along the lower River Rhine. - River Res. Appl. 19: 353374.

GutI, G. (1996): Species composition of juvenile (0-group) fish assemblages in the Szigetköz floodplain of the Danube. - Tiscia 30: 49-54. 
Halls, A.S. \& Welcomme, R.L. (2004): Dynamics of river fish populations in response to hydrological conditions: a simulation study. - River Res. Appl. 20: 985-1000.

HALYK, L.C. \& BALON, E.K. (1983): Structure and ecological production of the fish taxocene of a small floodplain ecosystem. - Can. J. Zool. 61: 2446-2464.

Heiler, G., Hein, T. \& Schiemer, F. (1995): Hydrological connectivity and flood pulses as the central aspects for the integrity of a river-floodplain system. - Regul. Rivers: Res. Mgmt. 11: 351-361.

Holopainen, J., Tonn, W.M. \& Paszowski, C.A. (1997): Tales of two fish: the dichotomous biology of crucian carp (Carassius carassius) in northern Europe. - Ann. Zool. Fennici 34: 1-22.

Jungwirth, M., Muhar, S. \& Schmutz, S. (2000): Fundamentals of fish ecological integrity and their relation to the extended serial discontinuity concept. - Hydrobiologia 422/423: 85-97.

King, A.J., Humphries, P. \& LAKE, P.S. (2003): Fish recruitment on floodplains: the roles of patterns of flooding and life history characteristics. - Can. J. Fish. Aquat. Sci. 60: 773-786.

Leclerc, J. \& Desgranges, J.-L. (2005): Exploratory multiscale analysis of the fish assemblages and habitats of the lower St. Lawrence River, Québec, Canada. Biodivers. Conserv. 14: 1153-1174.

LeLEK, A. (1989): The Rhine river and some of its tributaries under human impact in the last two centuries. - In: Dodge, D.P. (ed.): Proceedings of the International Large River Symposium. Can. Spec. Publ. Fish. Aquat. Sci. 106: 469-487.

Lowe-McConnelL, R.H. (1975): Fish communities in tropical freshwaters. - Longman Inc., New York, $337 \mathrm{pp}$.

Merron, G., Bruton, M. \& La Hausse de la Louviere, P. (1993): Changes in fish communities of the Pongolo Floodplain, Zululand (South Africa) before, during and after a severe drought. - Regul. Rivers: Res. Mgmt. 8: 335-344.

Meyer, L. \& Hinrichs, D. (2000): Microhabitat preferences and movements of the weatherfish, Misgurnus fossilis, in a drainage channel. - Environm. Biol. Fishes 58: 297-306.

MidDELKOOP, H. (1997): Embanked floodplains in The Netherlands. Geomorphological evolution over various time scales. - Ph.D. thesis, Univ. of Utrecht, $341 \mathrm{pp}$.

Middelkoop, H. \& Haselen, C.O.G. (eds.) (1999): Twice a river. Rhine and Meuse in The Netherlands. - RIZA report 99.003. Rijkswaterstaat-RIZA, Arnhem, 127 pp.

Ministry of Transport, Public Works and Water Management (1998): Fourth National Policy Document on Water Management Government Decision, Abridged version. Ministry of Transport, Public Works and Water Management, Den Haag, 64 pp.

Miranda, L.E. \& LuCAS, G.M. (2004): Determinism in fish assemblages of floodplain lakes of the vastly disturbed Mississippi alluvial valley. - Trans. Amer. Fish. Soc. 133: 358-370.

MolLs, F. (1999): New insights into the migration and habitat use by bream and white bream in the floodplains of the River Rhine. - J. Fish Biol. 55: 1187-1200.

Navodaru, I., Buisse, A.D. \& Staras, M. (2002): Effects of hydrology and water quality on the fish community in Danube delta lakes. - Internat. Rev. Hydrobiol. 87: 329-348.

Petry, P., Bayley, P.B. \& MarkLe, D.F. (2003): Relationships between fish assemblages, macrophytes and environmental gradients in the Amazon River floodplain. - J. Fish Biol. 63: 547-579. 
PetTs, G.E. (1994): Rivers: dynamic components of catchment ecosystems. - In: CaLow, P. \& Petts, G.E. (eds.): The Rivers Handbook 2: 3-22. Blackwell, London.

RaAt, A.J.P. (2001): Ecological rehabilitation of the Dutch part of the River Rhine with special attention to the fish. - Regul. Riv. Res. Managem. 17: 131-144.

Regier, H.A., Welcomme, R.L., Steedman, R.J. \& Henderson, H.F. (1989): Rehabilitation of degraded river ecosystems. - In: Dodge, D.P. (ed.): Proceedings of the International Large River Symposium. Can. Spec. Publ. Fish. Aquat. Sci. 106: 86-97.

Schiemer, F. (2000): Fish as indicators for the assessment of the ecological integrity of large rivers. - Hydrobiologia 422/423: 271-278.

Schiemer, F., Baumgarter, C. \& Tockner, K. (1999): Restoration of floodplain rivers: The Danube restoration project. - Regul. Rivers: Res. Mgmt. 15: 231-244.

Schiemer, F. \& Waidbacher, H. (1992): Strategies for conservation of a Danubian fish fauna. - In: Boon, P.J., Calow, P. \& PeTts, G.E. (eds.): River conservation and management: 363-382. J. Wiley \& Sons, Chichester.

Schiemer, F., Zalewski, M. \& Thorpe, J.E. (1995): Land/water ecotones: intermediate habitats critical for conservation and management. - Hydrobiologia 303: 259-264.

SchlosSER, I.J. (1991): Stream fish ecology: a landscape perspective. - BioScience 41: $704-$ 712.

Schoor, M.M., Wolfert, H.P., Maas, G.J., Middelkoop, H. \& Lambeek, J.J.P. (1999): Potential for floodplain rehabilitation based on historical maps and present-day processes along the River Rhine, the Netherlands. - In: Marriott, S.B. \& AlexanDER, J. (eds.): Floodplains: interdisciplinary approaches. Geol. Soc. Spec. Publ. 163: 123-137. London.

Simons, H.E.J., Bakker, C., Schropp, M.H.I., Jans, L.H., KoK, F.R. \& Grift, R.E. (2001): Man-made secondary channels along the River Rhine (the Netherlands): results of post-project monitoring. - Regul. Riv. Res. Managem. 17: 473-491.

StAm, M.A., Wiegerinck, J.A.M. \& WeSterinK, H.J. (1999): Biologische monitoring zoete Rijkswateren. Samenstelling van de visstand in 1997/1998 op basis van vangsten met de kor, de ankerkuil en het electrisch schepnet. - RIVO-DLO report c053/99. RIVO, Ijmuiden, 19 pp. [in Dutch]

TEJerina-Garro, F.J., Fortin, R. \& Rodriquez, M.A. (1998): Fish community structure in relation to environmental variation in floodplain lakes of the Araquaia River, Amazon Bason. - Environm. Biol. Fishes 51: 399-410.

Ter Braak, C.J.F. \& Šmilauer, P. (1998): Canoco reference manual and user's guide to Canoco for Windows, Software for Canonical Community Ordination (version 4). Microcomputer Power, Ithaca, NY, USA, 52 pp.

Tockner, K., Baumgarter, C., Schiemer, F. \& Ward, J.V. (2000): Biodiversity of a Danubian floodplain: structural, functional and compositional aspects. - In: GopaL, B., JUNK, W.J. \& DAvIS, J.A. (eds.): Biodiversity in wetlands: assessment, function and conservation 1: 141-159. Backhuys Publ., Leiden.

Tockner, K., Schiemer, F., Baumgarter, C., Kum, G., Weigand, E., Zweimuller, I. \& WARD, J.V. (1999): The Danube restoration project: Species diversity patterns across connectivity gradients in the floodplain system. - Regul. Rivers: Res. Mgmt. 15: 245258.

TOCKNER, K. \& STANFORD, J.A. (2002): Riverine flood plains: present state and future trends. - Environ. Conserv. 29: 308-330. 
VAN DEN BRINK, F.W.B. (1994): Impact of hydrology on floodplain lake ecosystems along the lower Rhine and Meuse. - PhD Thesis, Kath. Univ. Nijmegen, 196 pp.

Van den Brink, F.W.B., Maenen, M.M.J., Van der Velde, G. \& Bij de Vaate, A. (1991): The (semi-)aquatic vegetation of still waters within the floodplains of the Rivers Rhine and Meuse in the Netherlands: historical changes and the role of inundation. Verh. Internat. Verein. Theor. Angew. Limnol. 24: 2693-2699.

Van den Brink, F.W.B., Van der Velde, G., Buijse, A.D. \& Klink, A.G. (1996): Biodiversity in the lower Rhine and Meuse river-floodplains: its significance for ecological river management. - Netherl. J. Aquat. Ecol. 30: 129-149.

Van den Brink, F.W.B., Van der Velde, G. \& Cazemier, W.G. (1990): The faunistic composition of the freshwater section of the river Rhine in the Netherlands: present state and changes since 1900. - In: KinZelbach, F. \& Friedrich, R. (eds.): Biologie des Rheins. Limnologie aktuell 1: 191-216. G. Fischer, Stuttgart.

VAN DER Molen, D.T. \& BuIJSE, A.D. (2005): An evaluation of the benefits of lowland riverfloodplain rehabilitation (the Rhine, the Netherlands). - Arch. Hydrobiol. Suppl. 155 (Large Rivers 15): 443-463.

Van Geest, G.J., Coops, H., Roijackers, R.M.M., Buijse, A.D. \& Scheffer, M. (2005): Succession of aquatic vegetation driven by reduced water-level fluctuations in floodplain lakes. - J. Appl. Ecol. 42: 251-260.

VAN URK, G. \& SMIT, H. (1989): The lower Rhine geomorphological changes. - In: PetTS, G.E. (ed.): Historical change of large alluvial rivers - Western Europe: 167-182. J. Wiley \& Sons Ltd., New York.

Ward, J.V., Tockner, K. \& SChiemer, F. (1999): Biodiversity of floodplain river ecosystems: Ecotones and connectivity. - Regul. Rivers: Res. Mgmt. 15: 125-139.

Welcomme, R.L. (1979): Fisheries ecology of African floodplains. - Longmans, London, $317 \mathrm{pp}$.

WinemilleR, K.O. \& JePSEN, D.B. (1998): Effects of seasonality and fish movement on tropical river food webs. - J. Fish Biol. 53, Suppl. A: 267-296.

Winemiller, K.O., Tarim, S., Shormann, D. \& Cotner, J.B. (2000): Fish assemblage structure in relation to environmental variation among Brazos River oxbow lakes. Trans. Amer. Fish. Soc. 129: 451-468.

Winter, H.V., Hartgers, E.M., Wiegerinck, J.A.M. \& Westerink, H.J. (2000): Biologische monitoring zoete Rijkswateren. Samenstelling van de visstand in 1999 op basis van vangsten met fuiken en zalmsteken. - RIVO-DLO rapport c010/00, $32 \mathrm{pp}$. [in Dutch]

Accepted: 23 March 2006. 